\title{
Congenital absence of sternum in an infant
}

\author{
Anubha Shrivastava, Shahid Akhtar Siddiqui
}

Department of Pediatrics, Moti Lal Nehru Medical College, Allahabad, India

Correspondence to Dr Shahid Akhtar Siddiqui, sha.akht@yahoo.com

Accepted 26 January 2017

\section{DESCRIPTION}

A female baby aged 6 months, born to nonconsanguineous parents presented with anterior chest wall deformity since birth. On examination, an absent palpable sternum along with paradoxical respiratory movements with visible cardiac contractions and vasculature were seen beneath a thin layer of skin which led to the diagnosis of congenital absence of the sternum (figure 1 and video 1). The rest of the examination was found to be normal with no other obvious congenital anomalies. CT scan of the thorax showed mild shift of the mediastinum towards the right side with the pericardium abutting the anterior chest wall and absence of ectopiacardis. There was no other associated underlying malformation.

Congenital complete sternal cleft results from failure of the process of midline mesenchymal

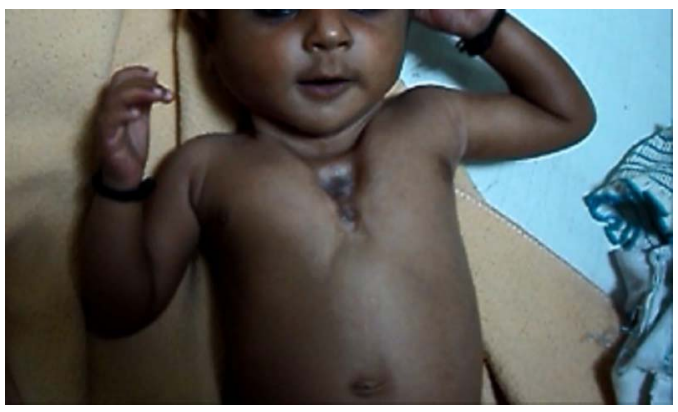

Figure 1 The absent sternum along with visible cardiac contractions and vasculature were seen beneath a thin layer of skin.

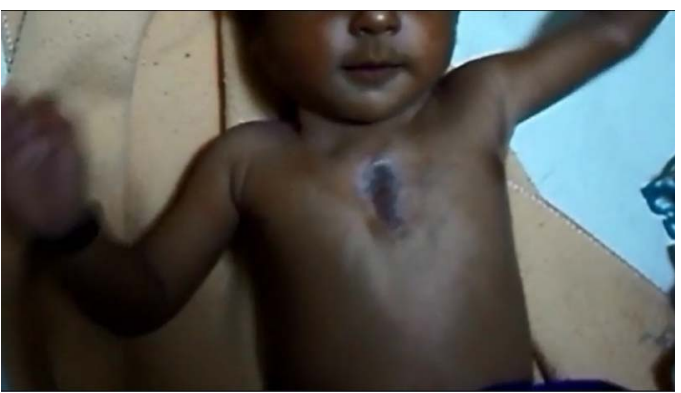

Video 1 The absent sternum along with visible cardiac contractions and vasculature were seen beneath a thin layer of skin. strip fusion during embryonic development. ${ }^{1}$ These patients are at increased risk of mediastinal injury, hypothermia and insensible fluid losses. ${ }^{2}{ }^{3}$ It may be associated with Cantrell's pentalogy, PHACES syndrome and Poland syndrome. Reconstructive surgery of absent sternum should be performed by primary closure using combined periosteal advancement flap and sliding osteochondroplasty during the neonatal period when the chest wall is highly compliant and closure can be achieved without significant cardiopulmonary compromise. $^{23}$

\section{Learning points}

- Congenital absence of the sternum is a rare malformation of the chest wall which results from failure of the process of midline mesenchymal strip fusion during embryonic development.

- Patients with complete sternal cleft are at increased risk of mediastinal trauma, hypothermia, increased insensible fluid losses, cyanosis and recurrent infections of the chest.

- With increasing age, surgical correction becomes difficult due to a decrease in compliance of the chest wall necessitating early surgical correction in the neonatal period.

Acknowledgements The authors thank Rahul, Aishwarya and Prabha.

Contributors AS worked up the case and prepared the final manuscript. SAS followed up the case, wrote the manuscript and reviewed the literature.

Competing interests None declared.

Patient consent Obtained.

Provenance and peer review Not commissioned; externally peer reviewed.

\section{REFERENCES}

1 Trivedi PM, Jagannathan R, Jagannathan N. Congenital absence of the sternum in a neonate. Anesthesiology 2014;120:752.

2 Torre M, Rapuzzi G, Carlucci M, et al. Phenotypic spectrum and management of sternal cleft: literature review and presentation of a new series. Eur J Cardiothorac Surg 2012;41:4-9.

3 Mazzie JP, Lepore J, Price AP, et al. Superior sternal cleft associated with PHACES syndrome: postnatal sonographic findings. J Ultrasound Med 2003;22:315-19. 
Copyright 2017 BMJ Publishing Group. All rights reserved. For permission to reuse any of this content visit http://group.bmj.com/group/rights-licensing/permissions.

BMJ Case Report Fellows may re-use this article for personal use and teaching without any further permission.

Become a Fellow of BMJ Case Reports today and you can:

- Submit as many cases as you like

- Enjoy fast sympathetic peer review and rapid publication of accepted articles

- Access all the published articles

- Re-use any of the published material for personal use and teaching without further permission

For information on Institutional Fellowships contact consortiasales@bmjgroup.com

Visit casereports.bmj.com for more articles like this and to become a Fellow 